\title{
Küresel Sağlık Sorunu ‘Obezite’: Güncel Bir Gözden Geçirme
}

\section{Global Health Problem 'Obesity': A Current Review}

\author{
Ziya Berberoğlu ${ }^{1}$, Çiçek Hocaoğlu ${ }^{2 *}$ \\ ${ }^{1}$ İz Beslenme \& Psikoloji Danışmanlık Merkezi, Rize, Türkiye \\ ${ }^{2}$ Recep Tayyip Erdoğan Üniversitesi Tıp Fakültesi, Psikiyatri Anabilim Dalı, Rize, Türkiye \\ e-mail: berberogluziya@gmail.com, cicekh@gmail.com \\ ORCID: 0000-0002-1920-2396 \\ ORCID: 0000-0001-6613-4317 \\ *Sorumlu yazar/ Corresponding Author: Çiçek Hocaoğlu \\ Gönderim Tarihi / Received: 25.02.2021 \\ Kabul Tarihi / Accepted: 22.06.2021 \\ DOI: $10.34087 /$ cbusbed.886473
}

Öz

Obezite günümüzde tüm dünyada en önemli halk sağlığı sorunlarından biri olarak kabul edilmektedir. Görülme oranları her geçen gün artan obezite, fiziksel, psikolojik ve sosyal pek çok soruna yol açarak yaşam kalitesini olumsuz etkilemektedir. Dengesiz beslenme ve fiziksel egzersiz eksikliği sonucu diyabet, hipertansiyon ve kardiyovasküler hastalıklara neden olabilmektedir. $\mathrm{Bu}$ nedenle obezite ülkelerin sağlık sistemlerine getirdiği yük, sağlık harcamalarında önemli bir yer tutmasının yanı sıra en önemli morbidite ve mortalite nedenlerin başında gelmektedir. Obezitenin gelişiminde genetik yatkınlıklar, çevresel ve psikolojik faktörler arasında karmaşık bir etkileşim söz konusudur. Obezite ile mücadelede yaşamı daha sağlıklı ve kaliteli hale getirmek için yeterli ve dengeli beslenme alışkanlıklarının kazanılması ile fiziksel egzersizin arttırılması gerekmektedir. Obezitenin tedavisinde kişiye özgü tedavi uygulamalarının yanı sıra psikolojik değişkenlerin etkisi dikkate alınmalıdır. Obezitenin tedavisinde kullanılan cerrahi ve cerrahi dışı geleneksel yöntemlerin başarısızlıkları da göz önüne alındığında, psikolojik değişkenlerin anlaşılması ve multidisipliner bir tedavi gerekliliği çok açıktır. Bu derlemede obezitenin etiyolojisi, tanı ve tedavisi güncel literatür bulguları eşliğinde ele alınmıştır.

Anahtar kelimeler: Obezite, Etiyoloji, Tanı, Tedavi

\begin{abstract}
Obesity is considered one of the most important public health problems all over the world today. Obesity, the incidence of which is increasing day by day, causes many physical, psychological and social problems and negatively affects the quality of life. Unbalanced diet and lack of physical exercise can cause diabetes, hypertension and cardiovascular diseases. For this reason, obesity is one of the most important causes of morbidity and mortality, as well as the burden that countries bring to health systems and an important place in health expenditures. There is a complex interaction between genetic predispositions, environmental and psychological factors in the development of obesity. In the fight against obesity, it is necessary to gain adequate and balanced nutrition habits and increase physical exercise in order to make life healthier and better quality. In the treatment of obesity, the effect of psychological variables should be taken into account, as well as individual treatment practices. Considering the failures of traditional surgical and nonsurgical methods used in the treatment of obesity, it is clear that the psychological variables should be understood and a multidisciplinary treatment is required. In this review, the etiology, diagnosis and treatment of obesity are discussed in the light of current literature findings.
\end{abstract}

Keywords: Obesity, Etiology, Diagnosis, Treatment 


\section{Giriş}

Dünya Sağlık Örgütü'ne (DSÖ) göre obezite, vücutta sağlığı bozacak ölçüde anormal veya aşırı yağ birikmesi olarak tanımlanmaktadır. Obezite, günümüzde özellikle gelişmiş ülkelerde en önemli sağlık sorunu olarak görülmekte olup, ICD-10'da hastalık olarak tanımlamıştır. Obezite tanısında yaygın olarak Beden Kitle İndeksi (BKİ) kullanılmaktadır. BKİ, kilogram olarak vücut ağırlığının, metre cinsinden boy uzunluğunun karesine bölünmesiyle hesaplanır (kg/m2). BKİ 18.5'in altındaysa zayıf, 18.5-24.9 arasında ise normal kilolu, 25-29.9 arasinda fazla kilolu, 30'un üzerinde ise obezite olarak sınıflandırılmaktadır [1]. Yetișkin erkeklerde vücut ağırlığının \%15-20'sini, kadınlarda ise \%25-30'unu yă̆ dokusu oluşturur. Erkeklerde bu oranın \% 25, kadınlarda ise \%30'un üzerine çıkması durumu obezite olarak tanımlanır. Diğer bir tanımlama ile vücuda alınan enerjinin, harcanan enerji miktarından fazla olması nedeniyle vücutta aşırı miktarda yağ depolanması ile obezite oluşmaktadır [2].

\section{Obezitenin Tarihçesi}

Tarihte obezitenin tartışılmaya ve ilk görülmeye başlaması 16. yüzyılın sonlarındadır. Diyet kısıtlaması ve egzersiz artışı Hipokrat' tan itibaren ifade edilmiştir. Ayrıca, Roma Dönemi'nden taş oymalarda masif obez kalıntılara rastlanmıştır. Tarihte şişmanlık ile ilgili pek çok tanım yapılmıştır. Tarihsel süreç içerisinde aşırı kilolu olma ve obezite hemen hemen tüm toplumlarda sağlık ve zenginlik belirtisi olarak algılanmış olup, bazen de doğurganlık ile ilişkilendirilmiştir. İnsanoğlunun tarih boyunca açlık, kıtlık ve yokluklarla mücadele ettiği düşünülürse böyle bir algının olması doğal görülmektedir. Ayrıca şişmanlık, güç, kudret, heybetli gibi terimleri çağrıştırmaktadır. İlk çağ tanrılarında şişmanlık / şişman kadın / ana tanrıça gücü ve hayatı ifade ederken, Orta Çă̆ ve Rönesans dönemlerinde ise zenginlik simgesi olarak görülmektedir. Günümüzde bile bu görüşün bazı bölgelerde devam ettiği görülmektedir. Afrika'da beslenmenin problem olduğu bölgelerde obezite zenginlik göstergesi olarak değerlendirilmektedir [3].

\section{Obezitenin Epidemiyolojisi}

Obezite oranları, önceki yıllarda daha çok gelişmiş, ekonomik düzeyi yüksek olan ülkelerde görülürken günümüzde, her ekonomik düzeyden ülkede görülen yaygın bir halk sağlığı sorunudur [4]. Diğer bir deyişle obezite, tüm ülkelerde sağlık sorunlarının başında yer almaktadır. DSÖ’nün verilerine göre obezite tanısı alan bireylerin sayısı tüm dünyada 400 milyon civarındadır [2]. Son birkaç on yılda, gelişmiş ve gelişmekte olan ülkelerde obezite yaygınlığı ciddi bir oranda artış göstermeye devam etmektedir [4].

Obezite oranlarındaki bu artış çoğunlukla Amerika Birleşik Devletleri (ABD)'de vurgulanmakta olup, günümüzde her 3 yetişkinden birinde obezite görülmektedir [5]. ABD'de 1991-1999 yılları arasında obezite yaygınlığ $\%$ 50 ila \%70 orasnında artış göstermiştir. Üçüncü Ulusal Sağlık ve Beslenme İncelemesi (NHANES III), ABD'de 20 yaşın üzerindeki genel nüfusun \%54,9'unun aşırı kilolu ve \%22,5'inin obez olduğunu göstermiştir. Yeni yapılan tahminlere göre, 2030 yılında birçok eyalette obezite sıklığının \%50’ye varacağı tahmin edilmektedir [6]. DSÖ tarafından Asya, Afrika ve Avrupa'nın 6 farklı bölgesinde yapılan ve 12 yıl süren MONICA adlı çalışmada (Kardiyovasküler Hastalıkta Belirleyicilerin ve Eğilimlerin Çokuluslu İzlenmesi) obezite yaygınlığında son 10 yılda \%10-30 arasında bir artış olduğu gösterilmiştir [7]. MONICA çalışmasının sonuçlarını destekler nitelikteki bir diğer veri ise OECD (Organisation for Economic Co-operation and Development -Ekonomik İşbirliği ve Kalkınma Örgütü), ülkeleri tarafından 2013'de yayınlanan sağlık raporudur. Burada, son on yllda obezitenin büyük oranda arttığı ve OECD ülkelerinde nüfusun yarısından fazlasının $(\% 52,6)$ aşırı kilolu ya da obez olduğu bildirilmiştir [8].

Gallus ve arkadaşları (2015) tarafından 16 farklı Avrupa ülkesinde yapılan bir çalışmada obezite yaygınlığ 1 kadınlarda \% 11,5 , erkeklerde ise \% 14,0; BKİ 25 'in üstünde olanların oranı kadınlarda \% 40,8, erkeklerde ise \% 54,5 olarak bulunmuştur. Bu oranlar 2010'da ABD verileriyle karşılaştırıldığında, obezite yaygınlığının Avrupa ülkelerinde yarıya yakın oranda daha az olduğu bildirilmiştir [9].

Türkiye'de obezite yaygınlığına baktığımızda ise batılı ülkelerden çok farklı olmadığı görülmektedir [10]. Erişkin toplumda obezite yaygınlığı özellikle kadınlarda \%30 gibi yüksek oranlara ulaşmış durumdadır. Sağlık Bakanlığı ve Hacettepe Üniversitesi tarafından 2010 tarihinde yapılan Türkiye Beslenme ve Sağlık Araştırması'na göre Türkiye'de obezite sıklığı; kadınlarda \%41,0, erkeklerde \%20,5 olarak, toplamda ise \%30,3 olarak bulunmuştur [11]. Türkiye'de 1997-1998 yıllarında toplam 540 merkezde, 20 yaş ve üzeri 24.788 kişinin incelendiği TURDEP-I (Türkiye Diyabet Prevalans) çalışmasında obezite yaygınlığı kadınlarda \%30, erkeklerde $\% 13$ ve genel toplumda \%22,3 olduğu bildirilmiştir [12]. Yaş dağılımı incelendiğinde obezite sıklığının 30'lu yaşlarda artış gösterdiği, 45-65 yaşları arasında en üst seviyeye geldiği görülmüştür. TURDEP-I çalışmasından 12 yıl sonra yapılan TURDEP-II çalışması yine aynı merkezlerde toplam 26.500 erişkinin katılımı ile yürütülmüştür. $\mathrm{Bu}$ çalışmada kadınlarda obezite sıklığ $\% 44$, erkeklerde $\% 27$ ve genel toplumda ise $\% 35$ olarak bildirilmiştir [13]. Bu iki çalışmanın sonuçları ele alındığında; Türkiye'de erişkin toplumunda standardize obezite prevalansının 1998'de \%22,3'ten, \%40 artarak 2010'da \%31,2'ye ulaştığ 1 saptanmıştır. On iki yılda kadınlarda obezite $\% 34$, erkeklerde ise \%107 oranında artmıştır.

\section{Obezitenin Etiyolojisi}

Obezite, karmaşık ve çok faktörlü bir hastalık olup, etiyolojisinde rol oynayan pek çok etken vardır. Obezite, fiziksel aktivitenin yanında vücudun harcayabileceğinden daha fazla kalori alınmasıyla ortaya çıkan enerji dengesizliğinden kaynaklanmaktadır. Obezitenin ortaya çıkmasına 
katkıda bulunan değişkenler; beslenme alışkanlıkları, genetik faktörler, yetersiz fiziksel aktivite, uykusuzluk, bazı ilaçların indüklediği kilo artışı, sigara, endokrin bozukluklar, etnisite ve yaş dağılımındaki değişkenler, gebelik yaşının artması, intrauterin etkiler, yüksek BKI'li bireylerin genetik olarak eşleşmesi, çeşitli enfeksiyonlar ve çevresel nedenler ile psikososyal etmenler şeklinde siralanabilir [14]. Obezitenin nedenleri sıralanırken bunlarla ilgili patogenez de tam olarak bilinmemektedir. Obezitenin nedenleriyle ilgili güncel yaklaşım, bu sıralanan nedenlerin birbiriyle ile ilişki içinde olduğu ve obezitenin multifaktöriyel bir hastalık olduğu şeklindedir [15]. Bireylerin obez olma nedenleri tam olarak açıklanamamış olup, genetik ve çevresel faktörlerin obezitenin oluşumunda katkılarının olduğunu, bunların yanında beslenme alışkanlıkları, fiziksel aktivite, psikolojik etmenler ve düşük sosyoekonomik seviye gibi faktörlerin de obeziteye neden olduğu bildirilmiştir [16].

Son zamanlarda yapılan geniş epidemiyolojik çalışmalar, obezitenin etiyolojisinin genetik faktörlerle olan ilişkisini göstermiştir. İkiz çalışmalarının sonuçlarına göre, obezitenin genetik yüklülüğü \%30-85 arasında olduğu bildirilmektedir [17]. Bu konudaki bir başka çalışmada obezitenin ortaya çıkmasında genetik fakörlerin \%25-40 oranında etkili olduğu belirtilmiştir [18]. 2010 yılında yayınlanana bir meta-analiz çalışmasında, mevcut ikiz çalışmalarını incelenerek, BKİ değişiklikleri üzerinde genetik faktörlerin güçlü, çevresel faktörlerin ise daha zayıf etkileri olduğu sonucuna varılmıştır. Aynı çalışmada evlat edinme çalışmalarının çocukluk çağı obezitesindeki önemi vurgulanmıştır. Çünkü evlat edinilen ve evlat edinen arasında benzerlikler bulunduğu ancak, genetik faktörlerin etkisini destekleyecek şekilde, ebeveyn ve biyolojik çocuğu arasındaki benzerliğin daha etkili olduğu belirtilmiştir[19].

Obezitenin etiyolojisinde rol oynayan bir diğer faktör ise beslenme şekli, fiziksel aktivite ve çevresel etkilerdir. Günümüzde obezitenin en sık nedeni enerjisi fazla olan gıdalara kolay ulaşılması ve durağan yaşam tarzıdır. Deveci'ye göre (2013) obeziteye yatkın olma durumu belirli bir noktaya kadar genetik faktörlere bağlı olmakla birlikte, obezitenin ortaya çıkması için obezojenik (obeziteye neden olan, şişmanlatan) bir çevreye de ihtiyaç vardır [20]. Bireyin bebeklikten itibaren öğrendiği beslenme şekli yaşımının ilerleyen dönemlerinde kilo alma şeklinde ortaya çıkmakta ve beslenme alışkanlıklarındaki yanlışlar obezite riskini arttırmaktadır. Obezitenin etiyolojisindeki çeşitli açıklamalar arasında en çok fikir birliği bulunan faktör, enerji alımı ve harcaması arasındaki dengesizliktir. Günde üç ana öğün, üç ara öğün tüketen kişiler ve günde bir veya iki ana öğün tüketen kişiler karşılaştırıldığında ilk grupta daha az sıklıkla obezite görüldüğünü saptanmıştır. Ayrıca, gelir düzeyi ve şehirleşmenin artması; yağ, doymuş yağ, şeker ve kompleks karbonhidrattan zengin diyet örüntüsünün oluşmasına neden olmaktadır [21].
Sedanter yaşam tarzı hem sağlık sorunlarına yol açmakta hem de obezitenin oluşmasına neden olmaktadır. Konuyla alakalı çalışmalar, yetersiz düzeyde fiziksel aktivitenin obezite de dahil pek çok sağlık sorununa yol açtığını göstermektedir [14,16]. Fiziksel aktivite azlığı, obezitenin ortaya çıkmasında en önemli nedendir. Modern toplumlarda daha az enerji harcayarak işlerin yürütülme imkanı, vücudun kullanamadığı enerjiyi yağ olarak biriktirmeye zemin hazırlamaktadır. Sosyoekonomik düzeyi yüksek olan ailelerin çocukları aşırı beslenme nedeniyle şişmanlarken, sosyoekonomik düzeyi düşük olan ailelerin çocukları ise dengesiz beslenmeye bağlı olarak şişmanlamaktadırlar. Diğer yandan sosyoekonomik seviyenin düşük olması sağlıklı yiyeceklere ulaşmayı güçleştirdiğinden olayı obeziteyle ilişkili olduğu da bildirilmiştir $[8,13]$. Ülkemizde yapılan bir çalışmada, kırsal kesimlerde yaşayan düşük sosyoekonomik seviyede olan bireylerin daha sık obeziteye yakalandı $\breve{g}_{1}$ belirtilmiştir [22]. Beyaz ve Koç (2011) tarafindan yapılan bir diğer çalışmada ise düşük eğitim düzeyine sahip yetişkin bireylerin BKİ değerinin yüksek eğitim düzeyine sahip bireylerin BKİ değerine göre daha yüksek olduğu bildirilmiştir [23].

\section{Obezitenin Gelişiminde Psikolojik Etmenler}

Obezite toplumda herkesi ilgilendiren önemli bir halk sağlığı sorunu olmasının yanında; psikolojik kökenli, somatik görünümlü kronik bir hastalı olarak tanımlabilir. Son dönemde obezitede psikolojik etmenlere olan ilgi artışmıştır. Faith ve arkadaşları (2011) tarafindan yapılan bir gözden geçirme çalışmasında, \%80 araştırmada obezitenin depresyona, \%53 araştırmada ise depresyonun obeziteye neden olduğunu bildirilmiştir [24]. Psikolojik durumla yeme davranışı arasında bağlantı olduğunu gösteren bir diğer çalışmada, depresyon, sıkıntı ve yorgunluk sırasında yeme miktarında artış olduğu; korku, gerilim ve ağrı sırasında ise yeme miktarda azalma olduğu belirtilmiştir. Aynı çalışmada öfke, depresyon, anksiyete ve yalnızlık gibi olumsuz duygularla emosyonel yeme davranışının ortaya çıtığ bildirilmiştir [25]. Emosyonel yeme dişında tıkınırcasına yeme davranışı da obezitenin sürmesinde önemli bir kavram olarak ele alınmıştır. Tıkınırcasına yeme dönemleri depresyon ve anksiyete gibi disforik mizaç nedeni ile tetiklenebilir. Buna rağmen bu durumun sıklığı, hangi duyguların tetikleyici olduğu ve emosyonel aşırı yemeye hangi etkenlerin eşlik ettiğine ait bilgilerimiz yine de azdir.

Obez bireylerde aşırı yeme üzerine açıklama getiren ilk kuramlar psikanalitik kurama dayanmakta olup, 1950'li yıllarda ortaya atılmıştır [3]. Obezite son yıllarda, sağlık, psikiyatri ve psikoloji alanlarının olmak üzere psikanalizin de odak noktası haline gelmiştir. Obez bireylerin çözümlenmemiş bağımlılık gereksinimlerine ve bu kişilerin psikoseksüel gelişimin oral dönemine fikse olduklarını vurgulamıştır. Oral döneme fiksasyon; aşırı bir iyimserlik veya karamsarlık, oburluk, hırs, bağımlılık ve sabırsızlık ile karakterize bir kişilik tipini oluşturmaktadır. Oral karakter yapısı etiyolojik açıdan 
önemlidir ve obezite ile güçlü bir ilişkisi vardır. Oral dönemde libido ağız, dudaklar ve dile daha çok yatırılır. Bu dönemde, ağız ve çevresi, doyum sağlayan, haz veren bölgedir. Emme, çiğneme ve yutma eylemlerinde belirginleşen içe alım, bu bölgenin ve oral dönem evresinin en temel işlevidir. $\mathrm{Bu}$ nedenle, obezite ve yeme davranışı arasında en çok ilișki kurulan dönem oral dönemdir. Oral dönemde anne ve bebek arasındaki alışverişte yaşanan dengesizlik de yeme davranışı üzerinde olumsuzluklara neden olmaktadır. Bu evrede bebeklerin davranışlarında öncelikli olarak içe alım ve doyum vardır. Burada annenin kişilik özellikleri oldukça önemli rol oynamaktadır. Güçsüz, kuşkulu, veremeyen ve kendi ihtiyaçlarıyla meşgul olan bir anne çocuğun sağlıklı bir şekilde almasını da engellemektedir. Düşgör'ün bildirdiğine göre; Bruch'un 1973 yılında yazdığı "Psychiatric Aspects of Obesity" makalesi psikanaliz bakış açısı ile obeziteyi anlamak için önemlidir. Bruch, obez bireyleri çoğunlukla olgunlaşmamış, bağımlı ve çaresiz olarak tanımlamaktadır. Bu özellikler oral bağımlılığın bir boyutudur. Diğer bir boyutta ise oral sadizm ambivalans, çiğneme ve isırma ile ilişkilendirilmektedir. Bruch'a göre bebeğin her ağlamasına ve huzursuzlanmasına meme ya da biberonla cevap veren anne, böylelikle onun her durumda varlığını koruyan bir oral tatmin ve ruhsal açlığını yaşamının ileriki dönemlerinde de oral doyum arayışında sürdürecektir. Yine aynı çalışmada Anzieu'un (1987) obez bedenin anlaml bir kapsayanının uzaydaki yeri olarak tanımlanabileceğini görüşüne de yer verilmiştir. $\mathrm{Bu}$ bedenin, ruhsal düzlemde, benliğin biçimsizleşmesini ve bozulmasını kışkırtarak boşluğa karşı ölçüsüz bir şekilde şişen ve patlama riski taşıyan bir zarfın biçimsel anlamlandırıcısı olarak yorumlanabilir. Deri benlik kavramı üzerinden obeziteyi incelediğimizde, bireyin bedeninin etrafında sarılı olan bu doğal çeperi bir koruma kalkanı olarak kullandığı düşünülmektedir [26].

Obezitenin gelişimini açıklayan bir diğer kuram ise öğrenme kuramıdır. Bu kuram, erken çocukluktaki deneyimler yaşam boyu yeme alışkanlıklarını etkilediğini söylemektedir. Bazı aileler şişman çocukların daha sağlıklı ve mutlu olduğunu düşünürler. Bazı çocuklar da ailesini memnun edebilmek için daha fazla yemek yemektedirler. Ebeveynler çocuklarına fazla miktarda yiyecek tüketmeleri konusunda sözlü ya da sözsüz iletiler verir. Böylelikle, çocuklar fazla yemeyi öğrenecek ve böyle yaptıkça da ödüllendirilecektir. Aileler tarafından "biraz daha ye" sıklıkla söylenir ve çocuklar yedikleri zaman övgü alırlar. Ebeveynler çocuklarının kendi kendilerini ayarlama becerilerini görmezden gelip, yeme davranışları üzerinde bir baskı ve kontrol kurmaya çalışırsa, çocuk bu beceriyi kazanamaz. Çocukların yeme davranışı üzerinde içsel ve kişisel denetimleri gelişmez. Ailenin kontrolü ve denetimi ortadan kalktığında ise, bu çocukların kendilerini denetlemeleri yetersiz kalır ve iştah uyandırıcı yiyecekler karşısında aşırı yeme önlenemez. Çünkü bu çocuklar, iç açlık uyaranlarına değil, dış yiyecek uyaranlarına yanıt vermeyi öğrenmiştir.

Obezitenin gelişimini açıklayan bir diğer model ise davranışçı kuramdır. Obezite, kişiyi rahatsız eden olumsuz duyguları azaltmak amacıyla uygun olmayan yeme davranışlarının olumsuz pekiștireç olarak kullanılmasıyla ortaya çıkan öğrenilmiş bir durumdur. Davranışçı modeller obezitenin ilk olarak, pekiştirilen ve aşırı yemeye neden olan uygunsuz yeme alışkanlıklarından ve ikinci olarak ise, öğrenme teorisinin ilkelerine göre yine pekiştirici özelliği olan egzersiz yokluğundan kaynaklandığını savunmaktadır. Bilişsel-davranışçı modele göre; bilgiyi işleme sürecinde sistematik yanlışlar olduğu, hem diş çevreden gelen bilgiler hem de içten gelen bilgilerin çarpıtıldığ 1 ve bunun sonucunda obez bireylerin bilişsel çarpıtmalar ve işlevsel olmayan tutumlara sahip oldukları ileri sürülmektedir. Bu model, obezite ve sosyal destekle ilgili bilgi işlem sürecine ve duygulara odaklanmaktadır [27].

\section{Obezitenin Sonuçları}

Obezite, yaygınlığ beraberinde pek çok fiziksel, psikolojik, sosyal, ekonomik sorunlar getiren süregen ve çok faktörlü bir hastalıktır. Obezite, tedavi edilememesi ve tekrarlaması durumunda birey ve toplum sağlığı açısından ciddi yıkıcı sonuçlara neden olabilir. Obezite, insüline bağlı olmayan diyabetes mellitus, koroner kalp hastalığı, hipertansiyon, serebrovasküler hastalıklar, solunum güçlüğü, bazı kanser türleri, derin ven trombozu, gastrointestinal sistem hastalıkları, yağlı karaciğer ve siroz, dislipidemi, polikistik over sendromu, stres inkontinansı, lenfödem, obstrüktif uyku apnesi ve osteortrit gibi hastalıklara da neden olmaktadır [28]. Epidemiyolojik çalışmalarda obez bireylerde bazı hastalıkların daha fazla görüldüğü bildirilmektedir. Aşırı kilolu veya obez olan genç ve orta yaşlı erkekler ve kadınlar kalp hastalığı geliştirmeye daha zayıf olan akranlarına göre daha yatkındırlar. Obez insanların sadece koroner kalp hastalığı geliştirme riski fazla olmayıp, aynı zamanda bu nedenden dolayı mortalite oranları da yüksektir. Kilodaki her 5-8 kilogram artış koroner arter hastalığı ile miyokart infarktüsü ölüm riskini \%25 arttırmaktadır [29]. Obezite aynı zamanda bireysel ve halk sağlığı üzerinde etkisi olan, ekonomik ve sosyal kalkınmayı etkileyen, sağlık-bakım arz ve talebini arttıran ciddi bir sağlık sorunudur. Obezitenin doğrudan maliyetinin ABD'de 70 milyar dolar civarında olduğu, bunun sağlık harcamalarının \% 7'sini, Avrupa da ise \% 6'sını kapsadı̆̆ düşünülmektedir. $\mathrm{Bu}$ duruma dolaylı maliyet eklendiğinde ise, yapılan harcamalar daha da yükselmektedir [4]. Obezite tıbbi maliyetlere ek olarak; işgücü piyasası üretkenlik maliyeti kaybı, obeziteye bağlı hastalıklar nedeniyle işine devam edemeyen çalışanların üretkenlik maliyeti, çalışanların işte üretkenliğinin azalması, erken ölümler, engellilik, ücret oranlarının artması ve sigorta kurumlarının zararı 
gibi dolaylı olarak ekonomiyi etkileyen diğer maliyetlere de yol açmaktadır.

\section{Obezitenin Psikolojik Sonuçarı}

Halk sağlığı açısından büyük bir problem olan obezite, bazı araştırmacılar tarafından psikosomatik bir hastalık olarak da görülmektedir $[15,28]$. Obezitenin psikolojik faktörler ve psikiyatrik hastalıklarla ilişkisi birçok çalışmada bildirilmiş olup; bu çalışmaların sonuçları birbirleriyle çelişkilidir [24,25]. Erken araştırmalarda yöntemsel farklılıklar içeren çalıșmaların karşılaștırılmasında obezite ve ruh sağlığı arasındaki ilişkide çelişkili sonuçlar elde edilmiştir [30].

Crisp ve Guiness tarafindan 1976 yılında "Jolly Fat" (neşeli şişman) hipotezi ileri sürülmüştür. $\mathrm{Bu}$ hipotezde, orta yaş grubu obez kadınlarda anksiyetenin, erkeklerde hem anksiyetenin hem depresyonun düşük olduğunu bildirmişlerdir [31]. Obez bireylerde psikiyatrik bozuklukların görülme sıklı̆ı̆ını araştıran ilk çalışmalarda normal popülasyondan farklı bir psikopatolojinin saptanmadığı bildirilmiştir. Obezite ve psikopatoloji ilişkisinin geçmişten bugüne kadar tartışmalı bir konu olduğu literatür taramasında ilk göze çarpan bulgudur. Bazı epidemiyolojik çalışmalar, obezite ve psikiyatrik bozukluklar arasında bir ilişkinin olduğunu bildirmiştir [24,25]. Toplum temelli olarak yapılan bir diğer çalışmada ise, obezite ve psikiyatrik bozukluklar arasında pozitif bir iliş̧ki bulunduğu bildirilmiştir. Bu bozukluklar en fazla duygudurum ve anksiyete bozukluklarıdır [32]. Diğer taraftan da, bunun tersini söyleyen çalışmalar da bulunmaktadır [33].

Obezite ve depresyon ilişkisinin incelendiği, Kanada'da yapılan bir çalışmada; depresyon yaygınlığı hem kilolu hem de obez bireylerde normal kilolu kișiler ile karşılaştıııldığında daha yüksek olduğu bildirilmiştir. Depresyon riskinin obez bireylerde \%30, fazla kilolu bireylerde ise $\% 40$ oranda arttı̆ 1 saptanmıştır. Ayrıca bu çalışmada obezite, genç kadınlar için depresyon riskini arttırdığı da bildirilmiştir [34]. Türkiye'de yapılan benzer bir çalışmada, obez kadınlarda psikiyatrik bozukluk yaygınlığının kontrol grubuna göre daha yüksek olduğu belirtilmiştir. Psikiyatrik bozukluk oranlarının obez kadınlarda $\% 60$, kontrol grubunda ise $\% 9,1$ olduğu bildirilmiştir. Çalışmada depresif bozukluk dışında en çok tespit edilen tanı anksiyete bozukluklarıdır [35]. Ülkemizde yapılan diğer bir çalışmada da, obez bireylerin \%81,3'ünde majör depresif bozukluk, $\% 22,6$ 'sında sosyal fobi, \%5,7 oranında ise yaygın anksiyete bozukluğu saptanmıștır. Bu çalıșmadaki bir diğer önemli bulgu ise, obez bireylerde anksiyete ve depresyon arasında bir korelasyon saptanmamıştır. $\mathrm{Bu}$ sonuç, obezitenin şiddetinden çok varlığının ruhsal bozukluklarla ilişkili olduğunu desteklemektedir [36]. Obezite ve depresyon ilişkisinin incelendiği yakın tarihli bir çalışmanın bulgularına göre, obezitesi olan kadınlardaki depresyon riskinin 3.1 kat daha yüksek olduğu; genel katılımcılarda ise obezite riskinin 2.9 kat daha fazla olduğu saptanmıştır. Çalışmanın sonucunda, obezitesi olan kadınların depresyon riskinin obezitesi olmayan bireylere ve erkeklere göre daha yüksek olduğu bildirilmiştir [37]. Tayvan'da yapılan bir diğer çalışmada 841 obezite hastası değerlendirilmiştir. Bu hastaların \%42'sinde en az bir psikiyatrik bozukluk saptanmıştır. Duygudurum bozuklukları (\%27,1), anksiyete bozuklukları $(\% 18,2)$ ve yeme bozuklukları $(\% 8,6)$ en yaygin olarak tespit edilen psikiyatrik bozukluklardır. Duygudurum bozuklukları ve yeme bozuklukları kadınlarda daha fazla saptanmış olup, anksiyete bozukluklarında cinsiyet fark bildirilmemiștir [38]. Türkiye'de 52 obez birey (46 kadın, 5 erkek) ve 43 normal kilolu birey ( 37 kadın, 6 erkek) ile yapılan bir diğer çalışmada da benzer bulgular bildirilmiştir. Obez bireyler kontrol grubuna göre anksiyete ve depresyon skorlarının yüksek olduğu bildirilmiş olup, bu psikolojik belirtilerin yaşam kalitesi, özgüven ve yeme tutumları üzerinde negatif etkisi olduğu bildirilmiştir [39]. Türkiye'de yapılmış bir diğer çalışmada, BKİ'nin depresyon ve aleksitimi ile ilişkisi incelenmiştir. Çalışmanın sonucunda, BKI ile şimdiki depresyon arasında pozitif yönlü bir ilişki bulunmuş olup, kadın cinsiyette daha güçlü olduğunu bildirmişlerdir. Çalışmada, yaşam boyu depresyon ile BKİ iliş̧ki bulunmamıştır. Çalışmanın bir diğer değişkeni olan aleksitimi ile BKİ arasında herhangi bir ilișki saptamamıșlar [40]. Tüm bu çalıșmalar gösteriyor ki; obezite, depresyon ve anksiyete bozuklukları arasında bir ilişki vardır. Bu nedenle, anksiyete ve depresyon belirtileri gösteren obez bireylerin takip edilmesi ortaya çıkabilecek psikiyatrik bozukluklar ve bunların olumsuz sonuçları açısından oldukça önemlidir. Ayrıca, obezitesi olan bireylerde psikiyatrik destek sağlanmasının yaşam kalitesi ve benlik saygısı üzerinde olumlu etkilerinin olabileceği düşünülmektedir.

Obezite ve cinsel işlev bozukluğu arasındaki ilişkinin de bildirildiği çalışmalar mevcuttur. Konu ile ilgili bir çalışmada diğer tüm değişkenlerin kontrol edilmesinden sonra, beden kitle indeksinin cinsel işlev bozukluklarıyla ilişkisinin olup/olmadığını kontrol etmek amaçlanmıştır. Araştırmanın sonucunda, her iki cinsiyette de diğer tüm değişkenler kontrol edildikten sonra BKİ'nin cinsel sorunlarla ilişkili olmadığı bildirilmiştir. Araştırmacılar, obezite ve cinsel işlev bozuklukları arasındaki ilişkinin diğer faktörlerin etkisiyle ortaya çıkabileceğini bildirmektedirler [41]. Konuyla ilgili yapılan bir derleme çalışmasında da obezitenin cinsel işlev bozukluklarının gelişiminde bir faktör olup olmadığını belirlenmesi için daha fazla çalışmaya ihtiyaç olduğu belirtilmiștir. $\mathrm{Bu}$ derleme çalışmasında, kilo vermeyle birlikte cinsel işlev bozukluklarında bir iyileşmenin olabileceği bildirilmiştir. Ancak bu etkinin de muhtemel bir etki olduğu ve başka faktörlerinde bu iyileşme üzerinde etkisi olabileceği tartışılmıştır [42]. Konuyla ilgili bir diğer derleme çalışmasında, aşırı kilolu ya da obez olma, normal kilolu bireylere göre erektil disfonksiyon (ED) riskinin \%30-90 oranında arttıracağını bildirmişlerdir. Öte yandan, ED'li kişiler, ED bulunmayan bireylerden daha ağırdır ve hipertansif ve 
hiperkolesterolemik olma ihtimalleri daha yüksektir. ED'nin ortaya çıkması obeziteyle doğrudan bir ilişki göstermese de, obezitenin getirdiği sağlık sorunları nedeniyle ED'nin oluşmasının riskini arttırmaktadır [43].

\section{Obezitenin Tedavisi}

Obezitenin tedavisi Antik Yunan'da Hipokrat'a kadar uzanmaktadır. Obezitenin çaresi Hipokrat'a göre çok çalışmak, sert bir yatakta uyumak, günde bir kez yemek, yağlı yiyecekler tüketmek ve bir gün içinde olabildiğince uzun süre çıplak olarak çalışmaktadır. Obezite, toplumun tüm kesimlerini ilgilendiren ve mortalite üzerine ciddi etkileri olan bir halk sağlığ sorunudur. Yaşam kalitesine etkileri ve ortaya çıkarttığ 1 sorunlar nedeniyle tedavi edilmesi gereken kronik bir hastalıktır. Obezite tedavisinde amaç, obeziteye ilişkin morbidite ve mortalite risklerini azaltmak, bireye yeterli ve dengeli beslenme alışkanlığı kazandırmak ve yaşam kalitesini arttırmaktır. Obezite tedavisi, yaşam boyu sürecek yeterli ve dengeli beslenme, artmış fiziksel aktivite ve davranış tedavilerini içeren bir kombinasyon tedavisidir Obezite tedavisinde amaç, ideal kiloya ulaşmaktan çok ilk önce obezitesi olan bireylere sağlıklı beslenme alışkanlığını kazandırmak, bireye özgü bir hedef belirleyerek bireyin ulaşabileceği bir kilo hedefi belirlemektir. Bütün bunların yanında en önemli amaç, verilen kilonun uzun dönemde de korunmasını sağlamaktır [44].

\section{Geleneksel Yöntemler}

\section{a. Tıbbi Beslenme (Diyet) Tedavisi}

Obezitesi olan ve fazla kilolu hastalar için düşük kalorili diyet uygulanır. Tibbi beslenme tedavisi obezite tedavisinde anahtar rol oynamaktadır. Diyet tedavisinin amacı, vücuda alınan enerji miktarı ile harcanan enerji miktarı arasında bir açık oluşturarak yăg depolanmasını azaltmaktır. Kilo kaybının korunması için yeme alışkanlığındaki değişikliğin kalıcı olması gerekir. Yapılması planlanan değişikliklerin ilk basamağı, obezitesi olan bireyin mevcut durumunu anlamak ve ortak bir bilinç ortamı oluşturmaktır. Bu nedenle diyet tedavisi kişiye özgü olarak düzenlenmelidir. Uygulanan diyet tedavisi kişinin alışkanlıkları ve günlük kullanımına uygun olmalıdır. Diyet tedavisi, vücut için gerekli olan protein, vitamin, mineral, esansiyel yağ asitlerini yeterli miktarlarda içermelidir [44].

\section{b. Egzersiz}

Fiziksel etkinliğin arttırılması hem obezite tedavisinde hem de verilen kilonun korunması açısından oldukça önemlidir. Obezitesi olan hastaların fiziksel aktivitelerini arttırırken, yaşam tarzlarında değişiklik yapabilmek, sedanter yaşam alışkanlarını azaltabilmek ve daha aktif bir yaşam sürdürebilmelerini desteklenmeleri amaçlanmalıdır. Obezitesi olan bireylerde enerji harcaması artırılırken diğer yandan da yaralanma riskinin en düşük düzeyde tutulması çok önemlidir. Önerilen egzersiz programının bireye özgü ve uygulanabilir olması oldukça önemlidir. Ayrıca, bireyin günlük yaşam alışkanlıkları ile uyumlu ve eğlenceli olması da sürdürülebilirlik açısından yararlı görülmektedir [44].

\section{c. Farmakolojik Tedavi}

Farmakolojik tedavi seçeneği, BKİ'si 27 ve üstü olup obezitenin yanında komorbid görülen hastalıkları olan, diyet ve fiziksel egzersiz gibi yöntemlerle kilo veremeyen bireyler için kullanılmaktadır. Obezite, metabolik kontrolü sağlamak için kronik ilaç tedavisinin tedavi modalitesi olarak kabul edilen ve tam bir iyileşmenin beklenmediği diyabetes mellitus ve hipertansiyona benzetilmektedir. Obezitede kullanılan farmakolojik tedavi birincil bir yöntem olmayıp, tamamlayıcı olarak kullanılmaktadır. Ayrıca, hiçbir koşul altında tek başına bir tedavi seçeneği olarak düşünülmemelidir. Çünkü gücü ve etkinliği bakımından düşüktür Obezite tedavisinde kullanılan sempatomimetik ilaçlar ve yağ emilimini değiştiren ilaçlar FDA (Food and Drug Administration) onayı almıştır. Bupropiyon ve fluoksetin gibi antidepresan ilaçlar ve antidiyabetik ilaçlar obezite tedavisinde FDA onayı almamış olup, kilo vermede etkilidir [44].

\section{d. Psikolojik Yaklaşımlar}

\section{Davranışçı Tedavi}

Obezitenin davranışçı tedavisinde bireylerin günlük yaşam alışkanlıklarının ve davranışlarının değiştirilmesi hedeflenmektedir. Davranışçı tedavide, obezitesi olan bireylerin gıda alımlarını ve fiziksel aktivite düzeylerini takip etmeleri ve düzenlemeleri amaçlanmaktadır. Bu amacın yanı sıra, yemek yemeyi tetikleyen ipuçlarının fark edilmesini sağlayarak bunlar üzerinde kontrol ve organizasyonun sağlanması da istenmektedir. Davranışçı tedavinin farklı basamakları bulunmaktadır. Bunlar, kendini izleme, uyaran kontrolü, yeme davranışının kontrolü, beslenme eğitimi, fiziksel aktiviteyi arttırmaya yönelik çalışmalar, davranış sözleşmesi ve kilo verme sonrası erişilen kiloyu sürdürmeye yöntemleri şeklinde siralanmaktadir [44].

\section{Bilișsel - Davrantşçı Terapi}

Bilişsel ve davranışçı terapi (BDT) etkinlik açısından üzerinde en çok çalışılmış terapilerdendir. Son dönemde, BDT yaklaşımları obezite tedavisinde önemli bir yer almaya başlamıştır. Obezite tedavisinde diyet ve egzersiz gibi geleneksel yöntemlerin bilişsel davranışçı müdahalelerle birleştirilmesi tedavinin ekinliğini arttırmakta ve kaybedilen kilonun kalıcılığını sağlamaktadır. BDT ile kişinin kilo vermesini engelleyen ve / veya kilo verdikten sonra kilonun korunmasına engel olan düşünce ve davranışlarını tespit edip, bunların daha işlevsel olanlarıyla değiştirilmelerini sağlamak amaçlanmaktadır [45].

Cooper ve arkadaşları, obezitenin tedavisinde BDT ile ilgili ortaya koyulan yeni modelde, hem davranış değişikliği hem de bilişsel değişikliklerin yapılması gerektiği de vurgulanmıştır. Cooper ve arkadaşları (2010), 3 yıllık izlem yaptıkları, 150 katılımcının olduğu çalışmada BDT, davranışçı tedavi ve rehberli kendi kendine yardım alan üç grup karşılaştırılmıştır. Katılımcıların sonuçları 3 yıl takip edilmiştir. Sonuçlarda ise, BDT uygulanan grupta $\% 10$ ve 
davranışçı tedavi yapılan grupta $\% 5$ oranında verdikleri kiloları korudukları bildirilmiştir. Katılımcıların büyük çoğunluğu verdikleri kiloların neredeyse tamamını geri almıştır. Araştırmacılara göre bu bulgular, obezitenin psikolojik tedavi üzerinde dirençli olduğunun söylenebileceğini ileri sürmektedirler [46]. Benzer bulguların saptandığı bir diğer çalıșmada ise; davranışsal zayıflama tedavisi ile BDT tedavisi alan iki grup karşılaştırıldığında önemli bir fark olmadığ bildirilmiştir [47]. Farklı sonuçların elde edildiği bir diğer çalışmada ise, tedavisine diyet ile birlikte BDT eklenen grup ile sadece egzersiz ve diyet tedavisi alan grup karşılaştırıldığında; BDT eklenen grubun verdikleri kiloyu korudukları, diğer grubun ise $\% 25$ oranında geri aldığı bildirilmiştir [48]. Bir diğer çalışmada ise, toplam 102 morbid obez hastaya uygulanan 10 haftalık BDT programının, bariatrik cerrahi adayı morbid obez bireylerin işlevsel olmayan yeme davranışı ve duydudurum belirtileri üzerinde iyileşme sağladığı bildirilmiştir [49]. Hiç tedavi almayan ya da sadece diyet ve egzersiz tedavisi alan grup ile BDT temelli tedavi alan grubun tedavi sonuçlarına bakıldığında BDT alan grubun kilo vermede daha başarılı olduğu bildirilmiştir [50]. Cooper ve Fairburn tarafindan 2001 yılında kilo kayb1 tedavisine özel olarak geliștirilen bir BDT modeli önerildi ve BDT ile davranışsal kilo kaybı tedavisinin etkinliğini karşılaştıran geniş çaplı bir araştırma gerçekleştirildi. Kilo kaybına özel olarak geliştirilen BDT'nin daha etkili olduğunu saptamışlardır [51]. Diğer yandan kilo kaybına özel olarak geliştirilen BDT ile standart BDT arasında herhangi bir fark olmadığını bildiren çalışmalar da bulunmaktadır [52,53]. Bahsedilen araştırmalar göstermektedir ki, BDT'nin kilo verme ve yaşam kalitesini iyileştirme üzerinde önemli etkileri vardır. Ancak uzun dönem etkileri konusunda literatürde tutarsızlıklar olduğu görülmektedir. Obezite temelli yapılan BDT çalışmalarında ortaya çıkan tutarsızlıklar, hasta seçimine ve çalışmanın yöntemine bağlı olarak; kilo alımına neden olan faktörlerin karmaşık bir yapıda olduğunu söyleyebiliriz. Türkiye'de yapılmış bir tez çalışmasında, obezite tedavisinde bilişsel davranışçı grup psiko-eğitiminin etkinliği araştırılmıştır. Yimi dokuz kişiden oluşan örneklem iki gruba ayrılmış olup, kontrol grubuna sadece yeme planı verilmiştir. On dört katılımcıdan oluşan psikoeğitim grubu sekiz hafta boyunca iki saat süren psiko-eğitime katılmıştır ve diyetisyen tarafindan yazılan yeme planını uygulamaları beklenmiştir. Çalışmanın sonucunda ise, psiko-eğitim grubunda BKİ ve genel psikopatoloji düzeylerinde anlamlı bir düşüş gözlenirken, kontrol grubunda herhangi bir fark saptanmamıştır [54].

Davranışçı tedavi ve BDT'nin karşılaştırıldığı bir çalışmada, 24 obez hasta değerlendirilmiştir. Sadece davranışsal tedavi alanlar akut dönemde kilo kaybı yaşarken, 12 aylık izlemde BDT alan grupta daha fazla kilo kaybı olduğu bildirilmiştir [55]. Davranışsal kilo kaybı tedavileri, randomize kontrollü çalışmalarda tek başına diyet ve egzersiz tedavilerine oranla belirlenmiş etkinliği olan ve en çok araştırılan tedavi yöntemidir. Davranışsal kilo kaybı tedavilerinin etkinliğinin bakıldığ bulunmaktadır. Tedavi sonrası izlem sürelerinin kısıtlı olması davranışçı stratejilerin uzun dönem etkileri hakkında çıkarım yapmak için yetersiz kalmaktadır.

\section{Bariatrik Cerrahi}

"Bariatrik" Yunanca bir kelime olmakla beraber, "baros" kelimesi ağırlık, "iatrike" kelimesi ise tedavi anlamına gelmektedir. BKI'nin 40 ve üzerinde olması morbid obezite olarak tanımlanmaktadır. Morbid obezitenin tedavisinde ilk olarak beslenme tedavisi, egzersiz, farmakoterapi, davranış terapisi gibi geleneksel yöntemler kullanılmakla birlikte, bu yöntemlerin uzun dönem etkisinin olmadı $\breve{g}_{1}$ bilinmektedir [56]. Obezite hastaları cerrahi olmayan geleneksel yöntemlerle kilo verme girişimleri sonucunda orta düzeyde bir kilo kayb1 elde etmektedirler. Tedavi sonrasında verdikleri kiloları hızlıca geri almaktadırlar. Konu ile ilgili yapılan araştırmalara göre, geleneksel yöntemlerle kilo kaybı yaşayan obez bireylerin kilolarının sadece \%10'unu kaybettiğini, 3 yıllık izlem sonuçlarına göre kaybedilen kiloların tekrar geri alındığını göstermiştir [56]. Obezitenin tedavisinde kullanılan geleneksel yöntemlerin yanında yeni yöntemlerin kullanılmaya başlanmasıyla birlikte hem dünyada hem de ülkemizde bariatrik cerrahi yaygin olarak kullanılmaya başlanmıştır. Tıbbi tedaviler tek başına obeziteyi önleyemediği ve tedavi edemediği için bariatrik cerrahinin ortaya çıkmasını sağlamıştır. Bu anlamda obezite cerrahisi güvenilir bir yöntem olarak değerlendirilmektedir Bariatrik cerrahinin tarihçesine baktığımızda, 50 yıldan uzun süredir kullanıldığ bilinmektedir. Kilo kaybının amaçlandığ 1 ilk cerrahi girişim 1953 yılında Minnesota Üniversitesi'nde yapılmıştır [56]. Cerrahi uygulamaları 1990'lı yıllarda artış göstermeye başlamış olup, ABD'de 1998 yilında 12.775 operasyon, 2004 y1lında ise 135.985 operasyon yapılmıştır. IFSO (International Fedaration for the Surgery of Obesity and Metabolic Diseases) raporlarına göre, 2013 yılında tüm dünyada 468.609 cerrahi uygulanmıştır [56].

\section{Bariatrik Cerrahi Endikasyonları}

BKI'si 30 ve üzerinde olan obezite hastaların tedavisinde ilk olarak geleneksel yöntemler denenmelidir. Geleneksel yöntemlerin sonucunda başarı elde edilemediği durumlarda bariatrik cerrahi seçeneği gündeme gelmelidir. Bariatrik cerrahi, geleneksel yöntemlerden farklı olarak daha fazla risk taşımakta ve bireyin hayatına ciddi bir kısıtlamalar getirmektedir. Bu kısıtlamalarla birlikte, davranışsal değişimlerin gerçekleşmesi de oldukça önemlidir. Bütün bu sebeplerden dolayı cerrahi öncesi adayların endokrinoloji, kardiyoloji, göğüs hastalıkları, anesteziyoloji-reanimasyon, genel cerrahi, beslenme ve diyet, psikiyatri ve psikoloji bölümlerinin oluşturduğu multidisipliner bir ekip tarafından kapsamlı bir şekilde değerlendirilmelidir. Böylelikle bireyin cerrahiye uygunluğu ve seçilecek yöntem saptanmaktadır. 
Amerika Birleşik Devletleri'nde NIH (National Institute of Health) tarafından bariatrik cerrahi ölçütler oluşturulmuştur [57]. Bu ölçütler şu şekilde sıralanmıştır:

1. BKİ'nin 40 ve üzerinde olması

2. BKI'nin 35 ve üzerinde ise hipertansiyon, tip 2 diyabetes mellitus, hiperlipidemi, eklem hastalıkları, uyku apnesi ve koroner arter hastalığ gibi komorbid hastalıkların olması

3. Geleneksel tedavi yöntemlerinin denenmiş ve başarısız sonuç alınmış olması

4. Bireyin psikiyatrik kontredikasyonun bulunmaması, psikiyatrik / psikolojik açıdan stabil olmas1

5. Bireyin genel anestezi için kontrendike durumunun bulunmaması

6. Cerrahiyi etkileyebilecek medikal probleminin bulunmamas1

7. Bireyin cerrahiye istekli olmas1 ve hem pre-op hem post-op süreçlerdeki olası riskleri kabul ediyor olmas1

\section{Bariatrik Cerrahi Kontrendikasyonlart}

Bariatrik cerrahide psikopatolojik kontrendikasyonlar günümüzde tartışmalı bir konudur. Psikopatolojik durumların ve psikososyal problemlerin sıklığına rağmen, bu durumların bariatrik cerrahi sonuçları üzerinde oluşturacağı etkiler bu alandaki bilimsel çalışmaların kısıtlılığı nedeniyle tartışılmaktadır. Bu konuda net bir görüş olmamasına rağmen Türkiye dışında yapılan çalışmalarda \% 51,5 uzman operasyon için engel olabilecek net bir psikiyatrik tanı bildirmezken, \% 44,3'ü madde kullanım bozukluğu, \%
41,8 yeme bozukluğu, \% 30,9 psikotik bozukluk, \% 25,8 majör depresif bozukluk ve \% 25,8'i intihar eğilimi gibi durumları kontraendikasyon olarak bildirmişlerdir [58]. Yüz seksensekiz bariatrik cerrahi programının incelendiği bir çalışmaya göre, yasa dışı (reçetesiz) ilaç kullanımı, aktif psikotik belirtiler, ağır mental retardasyon, şimdiki içicilik (current heavy drinking), intihar girişimi, aktif duygudurum bozukluğu belirtileri kontrendikasyon olarak alınmaktadır [59]. Konu ile ilgili yapılan bir derleme çalışmasında, demans, ağır mental retardasyon, psikotik bozukluklar ve psikoaktif madde kötüye kullanımı bariatrik cerrahide kontrendike durumlar olarak bildirilmiştir [60]. Ayrıca, tedaviye dirençli obsesif kompulsif bozukluk, ciddi düzeyde somatoform bozukluk, borderline kişilik bozukluğu gibi durumlar cerrahi sonrası uyumu bozacağından dolayı kontrendikasyon olarak değerlendirilmektedir. Ameliyat sonrası bakım için gerekenleri yapamayacak, sosyal desteği olmayan ve verilen bilgileri anlamakta güçlük çeken bireyler için de bariatrik cerrahi uygun bir yöntem değildir.

\section{Bariatrik Cerrahi Uygulamalart}

Obezitenin cerrahi tedavisinde farklı yöntemler kullanılmaktadır. Bu cerrahi işlemler, gıda alımını k1sitlayan, emilimi azaltan ya da her ikisinin birlikte kullanıldığı yöntemler şeklinde gruplanmaktadır. Bariatrik cerrahinin amacı, malabsorsiyona yol açarak veya besin alımını kısıtlama yoluna gidilerek kilo kaybının düşürülmesidir.Bariatrik cerrahi uygulamaları temelde üç ana başlık altında toplandığı görülmektedir [61].

Tablo1. Bariatrik Cerrahi Uygulamaları

\begin{tabular}{|rl|}
\hline Bariatrik Cerrahi Uygulamaları \\
\hline Kistlayıc1 (Restriktif) Uygulamalar \\
\hline 1. & Ayarlanabilir Gastrik Bant \\
\hline 2. & Sleeve Gastrektomi \\
\hline 3. & Vertikal Bant Gastroplasti \\
\hline Emilim & Bozucu (Malobsorbtif) Uygulamalar \\
\hline 1. & Biliopankreatik Diversiyon \\
\hline 2. & Duedonal Switch \\
\hline Kombine Bariatrik Prosedürler \\
\hline 1. & Roux-en-Y Gastrik Bypass \\
\hline
\end{tabular}

\section{Bariatrik Cerrahinin Etkinliği}

Bariatrik cerrahi ile cerrahi olmayan tedavilerin genel etkinliğini ölçmek için yapılan bir meta-analiz çalışmasında 11 farklı araştırma değerlendirilmiştir. Çalışmanın sonucunda, bariatrik cerrahinin, cerrahi olmayan tedavi seçeneklerine göre daha fazla kilo kaybı sağladığı elde edilmiştir. Ayrıca bariatrik cerrahi sonuçlarına göre, tip 2 diyabetes mellitus ve metabolik sendromda da daha yüksek remisyon oranları elde edilmiştir [62]. Post-op dönemde yapılan bir araştırmanın 
sonucuna göre, cerrahi sonrası 5 yıllık dönemde BKI'deki azalmanın 12 ila 17 olduğu tespit edilmiştir [63]. Benzer bir çalışmada da cerrahi sonrası kilo kaybının 4 yıl korunduğu saptanmıştır [64]. Cerrahi sonrası yapılan izlem çalışmalarına göre komorbid hastalıklarda da iyileşme olduğu tespit edilmiştir. Hipertansiyon, tip 2 diyabetes mellitus, miyokard infaktüsü, inme, kardiyovasküler hastalıklar, uyku apnesi, dislipidemi gibi komorbid problemlerde azalma tespit edilmiştir. Yapılan bir derleme çalışmasında, obezite cerrahisi sonrası kazanılan olumlu edinimler sonucunda mortalite oranlarında \%30-40 azalma sağlandığ 1 bildirilmiştir [65].

Cerrahi sonrası olumlu sonuçların yanında olumsuz sonuçların bildirildiği çalışmalar da yer almaktadır. Postop sonrası dönemde D, A, B12, B1 vitamin değerlerinde, folik asit, demir ve çinko eksikliği; bulantı ve kusma gibi gastrointestinal problemler; solunum güçlügü ve çeşitli bağımlılıklar saptanmıştır. [65].

\section{Sonuç}

Tüm dünyada ve ülkemizde obezite görülme s1klığ artmaktadır. Etiyolojisinde genetik, çevresel, fiziksel ve psikolojik çok sayıda faktörün rol oynadığı obezite hastalığı ile küresel çapta mücadele gerekmektedir. Gelișen teknolojik imkanlar ile birlikte bireylerin fiziksel aktivitelerinde azalmalar ve değișen beslenme alışkanlıkları obeziteye neden olabilmektedir. Yine stres, anksiyete gibi psikolojik faktörler de ruh sağlı̆̆ını etkileyerek obeziteye neden olabilmektedir. Obezite kardiyovasküler hastalıklar, diyabet, kanser gibi çok sayıda fiziksel hastalıkların yanı sıra düşük benlik saygısı, depresyon ve cinsel işlev bozukluklarına eşlik edebilmektedir. Bu nedenle ciddi yıkıcı sonuçları olan obezitenin tedavisi ve önlenmesinde genetik, endokrinoloji, fizik tedavi, bariatrik cerrahi, diyetisyen, psikolog ve psikiyatrlardan oluşan bir ekibin görev almasının önemi açıktır.

\section{Referanslar}

1. World Health Organization (1998) Obesity Preventing and Managing the Global Epidemic: Report of a WHO Consultation on Obesity, WHO/NUT/NCD/1998, The World Health Organization, Geneva.

2. WHO.(2015). Obesity and overweight.World health organization. http://www.who.int/mediacentre/factsheets/N311/en/index.html. (Accessed 2015 january)

3. Bray, G.A, Obesity: historical development of scientific and cultura ideas, International Journal of Obesity, 1990, 14(11), 909-926.

4. Blüher, M, Obesity: global epidemiology and pathogenesis, Nature reviews, Endocrinology, 2019, 15(5), 288-298.

5. Rosenthal, R.J, Morton, J, et al, Obesity in America, Surgery for obesity and related diseases: official journal of the American Society for Bariatric Surgery, 2017, 13(10), 1643-1650.

6. Borrell, L.N, Talih, M, Examining periodontal disease disparities among U.S. adults 20 years of age and older: NHANES III (1988 1994) and NHANES 1999-2004, Public health reports (Washington D.C. : 1974), 2012, 127(5), 497-506.

7. The World Health Organization MONICA Project (monitoring trends and determinants in cardiovascular disease): a major international collaboration. WHO MONICA Project Principal Investigators, Journal of Clinical Epidemiology, 1988, 41(2), 105140.

8. Devaux, M, Sassi, F, Social inequalities in obesity and overweight in 11 OECD countries, European Journal of Public Health, $2013,23(3), 464-469$
9. Gallus, S, Lugo, A, et al., Overweight and obesity in 16 European countries, European Journal of Nutrition, 2015, 54(5), 679-689.

10. Ural, D, Kılıçkap, M, Göksülük, H, et al, Türkiye'de obezite sıklığ ve bel çevresi verileri: Kardiyovasküler risk faktörlerine yönelik epidemiyolojik çalışmaların sistematik derleme, meta-analiz ve meta-regresyonu [Data on prevalence of obesity and waist circumference in Turkey: Systematic review, meta-analysis and meta regression of epidemiological studies on cardiovascular risk factors], Turk Kardiyoloji Dernegi Arsivi , 2018, 46(7), 577-590.

11. Sağlık Bakanlığı, Türkiye Beslenme ve Sağlık Araştırması 2010: Beslenme durumu ve alışkanlıklarının değerlendirilmesi sonuç raporu. Ankara: Sağlık Bakanlığı Sağlık Araştırmaları Genel Müdürlüğ̈̈, 2014.

12. Satman, I, Yilmaz, T, ve ark, Population-based study of diabetes and risk characteristics in Turkey: results of the Turkish Diabetes Epidemiology Study (TURDEP) 2002, Diabetes Care, 25, 15511556

13. Satman, I, Omer, B, ve ark, Twelve-year trends in the prevalence and risk factors of diabetes and prediabetes in Turkish adults, Europen Journal of Epidemiology, 2013, 28,169-180.

14. Wright, S.M, Aronne, L.J, Causes of obesity, Abdominal Imaging, 2012, 37(5), 730-732.

15. Conway, B, Rene, A, Obesity as a disease: no lightweigh matter. Obesity reviews: an official journal of the International Association for the Study of Obesity, 2004, 5(3), 145-151.

16. Archer, E, Lavie, C.J, Hill, J.O, The Contributions of 'Diet', 'Genes', and Physical Activity to the Etiology of Obesity: Contrary Evidence and Consilience, Progress in Cardiovascular Diseases, 2018, 61(2), 89-102.

17. Naukkarinen, J, Rissanen, A, Kaprio, J, Pietiläinen, K.H, Causes and consequences of obesity: the contribution of recent twin studies, International Journal of Obesity, 2012, 36(8), 1017-1024.

18. Loos, R.J, Genetic determinants of common obesity and their value in prediction, Best Practice \& Research, Clinical Endocrinology \& Metabolism, 2012, 26(2), 211-226.

19. Silventoinen, K, Rokholm, B, Kaprio, J, Sørensen, T.I, The genetic and environmental influences on childhood obesity: a systematic review of twin and adoption studies, International Journal of Obesity, 2010, 34(1), 29-40.

20. Deveci, E, Obezite cerrahisi adayı olan ve olmayan obez bireylerde yeme özellikleri, beden bölgesinden hoşnutsuzluk, tedavi motivasyonu ve psikopatolojinin değerlendirilmesi. İstanbul Üniversitesi, Yüksek Lisans Tezi, İstanbul.2013.

21. Balani, R, Herrington, H, Bryant, E, Lucas, C, Kim, S.C, Nutrition knowledge, attitudes, and self-regulation as predictors of overweight and obesity, Journal of the American Association of Nurse Practitioners, 2019, 31(9), 502-510.

22. Doğan, N, Toprak, D, Demir, S, Afyonkarahisar ilinde obezite prevalansı ve ilgili risk faktörleri, Turkiye Klinikleri Journal of Medical Sciences, 2011, 31(1), 122-32.

23. Beyaz, F, Koç, A, Antalya'da obezite yaygınlığg ve düzeyini etkileyen sosyo-ekonomik değişkenler, Akdeniz İIBF Dergisi, 2011, 11 (21), 17-45.

24. Faith, M. S, Butryn, M, et al, Evidence for prospective associations among depression and obesity in population-based studies, Obesity reviews : an official journal of the International Association for the Study of Obesity, 2011, 12(5), e438-e453.

25. Monda, V, La Marra, M, et al, Obesity and brain illness: from cognitive and psychological evidences to obesity paradox, Diabetes, metabolic syndrome and obesity: targets and therapy, 2017, 10, 473479.

26. Düşgör, B, Ergenlikte obezite ve beden: psikanalitik bir inceleme, Turkiye Klinikleri Journal of Psychology-Special Topics, 2016, 1(2) 29-34.

27. Sarwer, D.B, Grilo, C.M, Obesity: Psychosocial and behavioral aspects of a modern epidemic: Introduction to the special issue, The American Psychologist, 2020, 75(2), 135-138.

28. Shen, C, Sambamoorthi, U, Rust, G, Co-occurring mental illness and health care utilization and expenditures in adults with obesity and chronic physical illness, Disease Management, DM, 2008, 11(3), $153-160$.

29. Wang, L, Liu, W, et al, Association of overweight and obesity with patient mortality after acute myocardial infarction: a meta-analysis of prospective studies, International Journal of Obesity, 2016, 40(2), $220-228$. 
30. Scott, K.M, Bruffaerts, R, et al, Obesity and mental disorders in the general population: results from the world mental health surveys, International Journal of Obesity, 2008, 32(1), 192-200.

31. Crisp, A.H, McGuiness, B, Jolly fat: relation between obesity and psychoneurosis in general population, British Medical Journal, 1976, 1(6000), 7-9.

32. Simon, G.E, Von Korff, M, et al, Association between obesity and psychiatric disorders in the US adult population, Archives of General Psychiatry, 2006, 63(7), 824-830.

33. Rhew, I.C, Richardson, L.P, et al, Measurement matters in the association between early adolescent depressive symptoms and body mass index, General Hospital Psychiatry, 2008, 30(5), 458-466.

34. McLaren, L, Beck, C. A, et al, The relationship between body mass index and mental health. A population-based study of the effects of the definition of mental health, Social Psychiatry and Psychiatric Epidemiology, 2008, 43(1), 63-71.

35. Özdel, O, Sözeri-Varma, G, ve ark, Obez kadınlarda psikiyatrik tan sıklığı, Klinik Psikiyatri Dergisi, 2011, 14, 210-217.

36. Eren, İ, Erdi, Ö, Obez hastalarda psikiyatrik bozuklukların sıklığı, Klinik Psikiyatri Dergisi, 2003, 6, 152-157.

37. Yanıkkerem, E, Obezitenin kadın sağlığına etkileri, Journal of Health Sciences of Kocaeli University, 2017, 3(1), 37-43.

38. Lin, H. Y, Huang, C. K, et al. Psychiatric disorders of patients seeking obesity treatment, BMC Psychiatry, 2013, 13, 1 .

39. Değirmenci, T, Kalkan, O.N, ve ark. Obezitede psikolojik belirtiler ve ilişkili etmenler, Nöropsikiyatri Arşivi, 2015, 52, 42-46.

40. Karagöl, A, Özçürümez, G, ve ark, Beden kitle indeksinin depresyon ve aleksitimi ile ilişkisi, Anadolu Psikiyatri Dergisi, 2014, 15,207213.

41. Kolotkin, R.L, Binks, M, et al, Obesity and sexual quality of life. Obesity (Silver Spring, Md.), 2006, 14(3), 472-479.

42. Rowland, D.L, McNabney, S.M, Mann, A.R, Sexual function, obesity, and weight loss in men and women, Sexual Medicine Reviews, 2017, 5(3), 323-338.

43. Rastrelli, G, Lotti, F, et al., Metabolically healthy and unhealthy obesity in erectile dysfunction and male infertility, Expert Review of Endocrinology \& Metabolism, 2019, 14(5), 321-334.

44. Jackson, V. M, Breen, D.M, et al., Latest approaches for the treatment of obesity, Expert Opinion on Drug Discovery, 2015, 10(8), 825839.

45. Dalle Grave, R, Sartirana, M, Calugi, S, Personalized cognitivebehavioural therapy for obesity (CBT-OB): theory, strategies and procedures, BioPsychoSocial Medicine, 2020, 14, 5 .

46. Cooper, Z, Doll, H.A, et al, Testing a new cognitive behavioura treatment for obesity: A randomized controlled trial with three-year follow-up, Behaviour Research and Therapy, 2010, 48(8), 706-713.

47. Munsch, S, Biedert, E, et al, A randomized comparison of cognitive behavioral therapy and behavioral weight loss treatment for overweight individuals with binge eating disorder, The International Journal of Eating Disorders, 2007, 40(2), 102-113.

48. Werrij, M. Q, Jansen, A, (2009). Adding cognitive therapy to dietetic treatment is associated with less relapse in obesity, Journal of Psychosomatic Research, 2009, 67(4), 315-324.

49. Gade, H, Hjelmesæth, J, et al., Effectiveness of a cognitive behaviora therapy for dysfunctional eating among patients admitted for bariatric surgery: a randomized controlled trial. Journal of Obesity, 2014 127936.

50. Rodriguez-Hernandez, H, Morales-Amaya, U.A, et al, Adding cognitive behavioural treatment to either low-carbohydrate or low-fat diets: differential short-term effects, The British Journal of Nutrition, 2009, 102(12), 1847-1853.

51. Cooper, Z, Fairburn, C. G, A new cognitive behavioural approach to the treatment of obesity, Behaviour Research and Therapy, 2001, 39(5), 499-511.

52. Lo Presti, R, Lai, J, et al, Psychological treatments for obesity in youth and adults, The Mount Sinai Journal of Medicine, New York, 2010, 77(5), 472-487.

53. Oğuz G, Karabekiroğlu A, ve ark. Obezite ve bilişsel davranışçı terapi, Psikiyatride Güncel Yaklaşımlar-Current Approaches in Psychiatry, 2016, 8(2), 133-144.

54. Yardımc1, B, The effectiveness of cognitive-behavioral group psychoeducation in the treatment of obesity, Yayınlanmamıs yüksek lisans tezi, İstanbul Bilgi Üniversitesi Sosyal Bilimler Enstitüsü, 2011, İstanbul.

55. Ünal, G.Ö, Obezitenin psikiyatrik yönü, tedavisinde davranıșçı ve bilişsel davranışçı terapi, Bilişsel Davranışçı Psikoterapi ve Araștırmalar Dergisi, 2018, 7(1),31-41.

56. Phillips, B.T, Shikora, S.A, The history of metabolic and bariatric surgery: Development of standards for patient safety and efficacy, Metabolism: Clinical and Experimental, 2018, 79, 97-107.

57. Garvey, W.T, Mechanick, J.I, et al., American Association of Clinical Endocrinologists and American College of Endocrinology, Comprehensive Clinical Practice Guidelines for Medical Care of Patients with Obesity, Endocrine practice:official journal of ithe American College of Endocrinology and the American Association of Clinical Endocrinologists, 2016, 22 Suppl 3, 1-203.

58. Ribeiro, G, Giapietro, H.B, et al, Depression, anxiety, and binge eating before and after bariatric surgery: problems that remain, Arquivos Brasileiros de Cirurgia Digestiva: $A B C D=$ Brazilian archives of digestive surgery, 2018, 31(1), e1356.

59. Bauchowitz, A.U, Gonder-Frederick, L.A, et al, Psychosocia evaluation of bariatric surgery candidates: a survey of present practices, Psychosomatic Medicine, 2005, 67(5), 825-832.

60.Sevinçer, G.M, Coşkun, H, ve ark, Bariatrik cerrahinin psikiyatrik ve psikososyal yönleri, Psikiyatride Güncel Yaklaşımlar,2014, 6(1), 32-44.

61. Rahman, R, Azagury, D.E, Novel technologies and techniques in bariatric surgery, Minerva chirurgica, 2017, 72(2), 125-139.

62. Buchwald, H, Buchwald, J.N, Metabolic (Bariatric and Nonbariatric) Surgery for Type 2 Diabetes: A Personal Perspective Review, Diabetes Care, 2019, 42(2), 331-340.

63. Chang, S.H, Stoll, C.R, et al., The effectiveness and risks of bariatric surgery: an updated systematic review and meta-analysis, 20032012, JAMA Surgery, 2014, 149(3), 275-287.

64. Douglas, I.J, Bhaskaran, K, et al., Bariatric surgery in the United Kingdom: a cohort study of weight loss and clinical outcomes in routine clinical care, PLoS Medicine, 2015,12(12).

65. Öcal, H, Aygen, E, Obezitenin cerrahi tedavisi, Firat Tip Dergisi, 2018, 23, 78-87.

http://edergi.cbu.edu.tr/ojs/index.php/cbusbed isimli yazarın CBU-SBED başlıklı eseri bu Creative Commons Alıntı-Gayriticari4.0 Uluslararası Lisansı ile lisanslanmıştır. 